\title{
Re-enslavement, Rights and Justice in Nineteenth-Century Brazil ${ }^{1}$
}

\author{
Keila Grinberg \\ Department of History \\ Federal University of the State of Rio de Janeiro (UniRio) \\ Keila Grinberg, "Re-escravização, direitos e justiças no Brasil do século XIX," \\ in: Direitos e justiças: ensaios de história social, ed. Silvia Lara and Joseli \\ Mendonça (Campinas: Editora da Unicamp, 2006): 101-128. \\ Translated by Mark Lambert
}

The slaves Martha and Sabino had been with the Vaz da Silva family for a long time, living in Curvelo, Minas Gerais. It's hard to say exactly how long, but at least since João Vaz da Silva inherited them from his father. João lived with his wife, his children and the two slaves (there was also a third, Conrado, labeled as mentally deficient). Martha and Sabino remained captive until João reached old age, when, out of fear of approaching death and judgment, or for the good services rendered to the family, he freed Sabino and drafted freedom papers for Martha, who was to be released after her master had passed away.

Even before João's death, Sabino and Martha had no doubts as to the change in their status. After they received their freedom, they continued to reside with their masters, "reigning among them the equality of domestic intimacy, without distinction as to servile condition," and to interact with their masters "of their own free will, singing and dancing with them." But the harmony in the Vaz da Silva home lasedt only until João's death. Shortly thereafter, Martha, unhappy with her ex-mistress's interference in her quarrels with a certain Maria Bernardina, left.

Martha went to live in the home of Manoel Rodrigues Vianna. Because she was continually pursued by João Vaz da Silva's children (and heirs), who insisted that she return to their mother's service, she moved away from the city

1. I would like to thank Silvia Lara, Joseli Mendonça, Beatriz Mamigonian, Patricia Sampaio and Elciene Azevedo for their valuable comments on the Portuguese version. I also would like to thank Sueann Caulfield, Rebecca Scott and Kristin McGuire for commenting on and correcting the English version. 
where they lived. When she eventually decided to go back in 1860 , she, along with Sabino, was seized by the heirs. ${ }^{2}$

To justify this action, João's heirs stated that since their father was over eighty years old when he signed the letters of manumission for Martha and Sabino, he "was no longer in control of his facilities." They petitioned the court to nullify the letters and declare Martha and Sabino slaves, as they never should have ceased to be. They noted that "old age is a serious, irreversible illness" that affected most people over the age of 70 (according to paragraph 5, Title 104, Book 4 of the Ordenações Filipinas) - which implied, of course, that in freeing his slaves, João could not "be responsible for his actions since he was incapable of anything, and [of] any civil, judicial or extrajudicial act," and had not been able to "exercise rights or incur valuable obligations, especially in dealing with all of his assets to the detriment of his wife and children." The argument was precisely that property in Sabino and Martha constituted João's sole possessions, and as such, they could not be donated in such a manner, leaving his family in total poverty.

The attorney assigned to the former slaves made no headway with the claim that his clients' freedom was based on their "social and natural rights," or that Martha's and Sabino's freedom had been conferred "by a competent person."Nor did it help for him to denounce the "greed and inhumanity" that had motivated the intentions of the authors of the lawsuit. Nor was it enough to mention that any alleged imperfections in João Vaz da Silva's mental state would have to be proven, which had not been done, or that, since Sabino and Martha had lived as free people for more than six years, the law of prescription barred any action to reduce them again to slavery.

Discounting the attorney's arguments, Judge Antonio Carlos dos Reis agreed with the heirs that Sabino's and Martha's letters of freedom should be nullified. For him, the donation made by João had infringed upon the "vested rights" of his heirs, and was not justified by "the friendship that existed between defendants and said authors during the life of João Vaz da Silva, a friendship that could never harm the heirs." Therefore, even though "confining itself to a certain orbit which favors granting freedom," he declared Martha and Sabino captives, and as such, required them to provide the services that João's heirs demanded. ${ }^{3}$

For some time, the historiography of slavery and freedom in nineteenthcentury Brazil has focused on the possibility of achieving freedom through the courts, primarily through freedom lawsuits, i.e., lawsuits brought by slaves in order to achieve freedom. Sidney Chalhoub, Hebe Mattos, Eduardo Spiller Pena, Elciene Azevedo, Joseli Mendonça, and others have argued that freedom

2. Freedom lawsuit,1860. National Archives of Rio de Janeiro, Court of Appeals, cx. 3691, n. 6229

3. Idem. 
lawsuits contributed to the de-legitimation of slavery in Brazil over the nineteenth century. According to these authors, slaves and their lawyers used freedom suits not only to demand the freedom of individual slaves, but, at least after the 1860 s, to reshape social relations between masters and slaves, to expand the rights of slaves and freedpersons, and even to militate for general emancipation. ${ }^{4}$

Perhaps due to the undisguised sympathy of historians for the abolitionist cause, little scholarly attention has been given to the practice of re-enslavement in the period. An exception is Judy Bieber Freitas's work, which demonstrates how the ending of the Atlantic slave trade ended up promoting re-enslavement practices in order to meet the demand for slaves in the Paraiba Valley. ${ }^{5}$

Yet just as there was an abundance of freedom lawsuits in the nineteenth century, there were also a great many cases brought by masters seeking to regain possession of their former or alleged slaves or by freedpersons seeking to maintain their status in the face of challenges to it. Over the course of the nineteenth century, the practice of reenslavement apparently lost its legitimacy. This led to an intense legal debate regarding the validity of laws that dealt with enslavement and revocation of manumission.

This article aims to understand the process by which reenslavement came to be regarded as illegitimate by analyzing the arguments of lawyers and judges in the lawsuits involving reenslavement that were heard by the Rio de Janeiro Court of Appeals in the nineteenth century. By emphasizing the role of legal debates that took place in the courts as a crucial arena in the fight against slavery, my goal is to draw attention to the importance of studying the debates over the civil status of a person-free or slave-from the perspective of law. In attempting to understand how Brazilian law was built upon the experience of slavery in nineteenth-century Brazil, I intend to contribute to the historiographical current that focuses on the history of law and legal practice in Brazil without abandoning the methods, themes, and historiographical debates of social history. ${ }^{6}$

4. For studies on slavery in the nineteenth Century that made use of lawsuits, see, for example, Sidney Chalhoub, Visões da liberdade, São Paulo, Companhia das Letras, 1990; Hebe Mattos, Das cores do silêncio, Rio de Janeiro, Nova Fronteira, 1998; Elciene Azevedo, Orfeu de carapinha, Campinas, Unicamp, 1999; Eduardo Spiller Pena, Pajens da casa imperial, Campinas, Unicamp, 2001; Joseli Mendonça, Entre a mão e os anéis, Campinas, Unicamp, 1999; Keila Grinberg, Liberata, a lei da ambigüidade, Rio de Janeiro, Relume Dumará, 1994. Keila Grinberg, O fiador dos brasileiros: escravidão, cidadania e direito civil no tempo de Antonio Pereira Rebouças. Rio de Janeiro, Civilização Brasileira, 2002.

5. Judy Bieber Freitas, "Slavery and social life: attempts to Reduce Free People to Slavery in the Sertão Mineiro, Brazil, 1850-1871”, Journal of Latin American Studies, Volume 26, Issue 03, October 1994, pp. 605-609.

6. In the field of social history, the first ones who utilized the resources of this area of history to study the law were the Brazilianists Stuart Schwartz and Thomas Flory in Schwartz, Sovereignty and Society in Colonial Brazil: The High Court of Bahia and Its Judges. Berkeley, Uni- 
When I studied the 402 freedom lawsuits that reached the Court of Appeals of Rio de Janeiro in the nineteenth century several years ago, in addition to analyzing their geographical origins, the period in which they occurred, and their outcomes, I classified them according to the argument that the plaintiffs-slaves-had presented to try to obtain their freedom. ${ }^{7}$

At the time, disregarding the possible differences among the various types of lawsuits, I analyzed only some of the arguments used by the slaves and their lawyers. Since I was interested in understanding the legal dynamics of the lawsuits, I ended up concentrating only on the best-known cases in the historiography at the time. I classified them according to the reasons that gave rise to each: "letter of manumission" when slaves argued that their masters or their heirs were granted manumission and then had gone back on their word; "free womb" when families of slaves argued that they were the children, grandchildren or great-grandchildren of people who had been illegally enslaved, whether because they were freedpersons or because they were of indigenous origin; and "the purchase of manumission", when slaves or third parties requested arbitration to determine their value in order to buy their freedom. ${ }^{8}$ Thus, because they addressed similar issues, I considered these lawsuits as a single group, and I sorted each according to the "type" of argument involved. (See chart 1)

Taking a second look at these cases, however, I have subsequently realized that among them were a set of cases that were fundamentally distinct. Although most were, in fact, freedom lawsuits, a significant number were originally classified as either "maintenance of freedom" or "enslavement" lawsuits (see chart 2).

When I paid attention to the differences expressed in these nineteenthcentury classifications, I realized that they were, by their nature, different kinds of freedom lawsuits, because they involved the question of re-enslavement. In freedom lawsuits, slaves-or, at least, individuals formally taken to be captives - had asked free men to sign petitions for them, arguing that they had reasonable grounds to sue their masters for their freedom.

In contrast, the lawsuits involving the maintenance of freedom were initiated by freedmen who sought to defend in court the right to maintain their legal status because they felt threatened by the possibility of re-enslavement. The maintenance of slavery lawsuits, in turn, were initiated by masters who wanted to reclaim slaves whom they claimed had been wrongly perceived as free. These

versity of California Press, 1973; and Flory, Judge and Jury in Imperial Brazil, 1808-1871: Social Control and Political Stability in the New State. Austin, University of Texas, 1981. See also, Sílvia H. Lara, Legislação sobre escravos africanos na América Portuguesa," Madrid, Fundación Tavera, 2000, pp. 18-19.

7. Grinberg, Liberata, especially chapter 2.

8. For examples of the analysis of cases with this line of argument, see, Chalhoub, "Visões da liberdade, chapter 2 . 
Chart \#1: Classification of the motives for freedom lawsuits of the Tribunal da Relação of Rio de Janeiro in "Liberata"

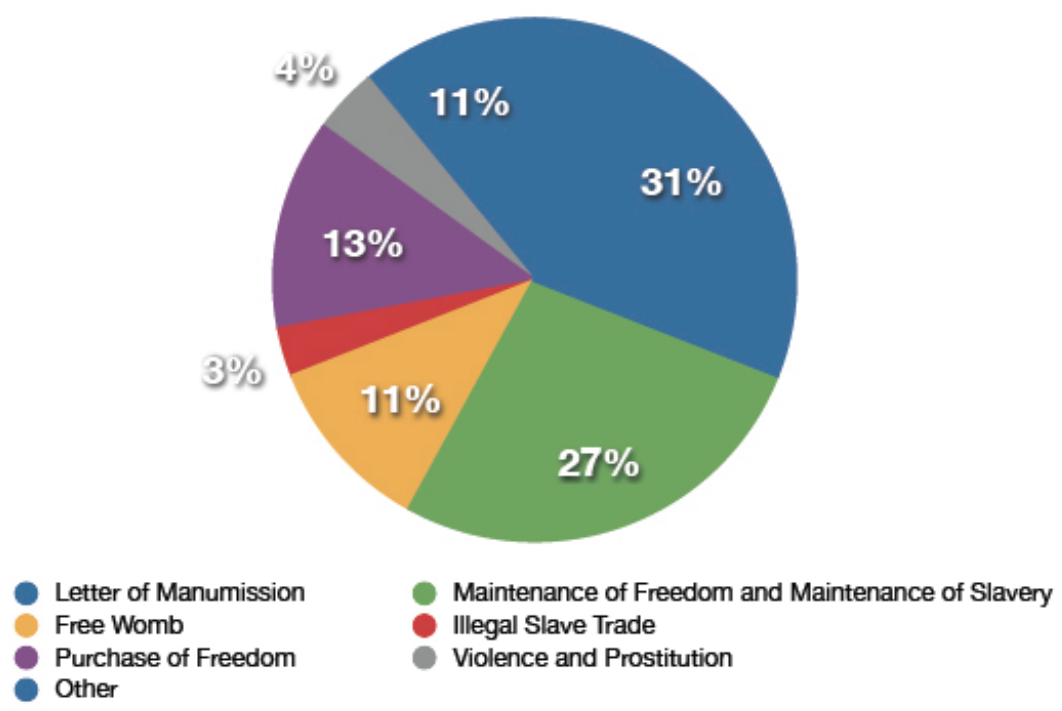

Source: Court of Appeals-National Archives-Rio de Janeiro. Total: 402 Freedom Lawsuits

Chart \#2: Maintenance of Freedom and Enslavement Lawsuits of the Tribunal da Relação do Rio de Janeiro

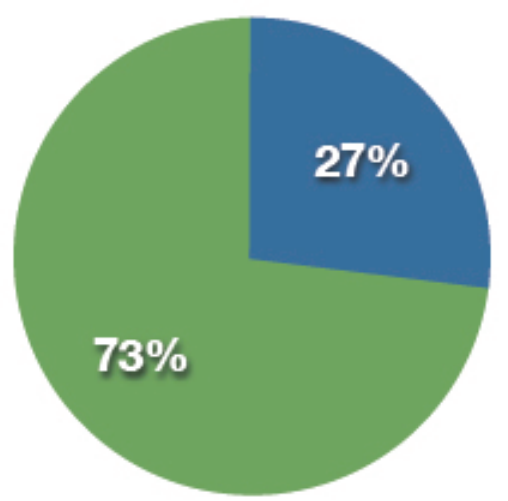

Maintenance of Freedom and Enslavement Lawsuits

Others

Source: Court of Appeals-National Archives-Rio de Janeiro. Total: 402 Freedom Lawsuits 
two types of lawsuits will be considered here as re-enslavement lawsuits, although they were not baptized with this name in the nineteenth century.

Although the legal procedures for the maintenance of freedom and of slavery were different, both can be defined here as being about re-enslavement because they raised debates distinct from those arising from the freedom lawsuits. In addition to checking the accuracy of the versions told by both parties, as one would in any case, in these cases it was necessary to determine the grounds on which it was possible to overturn a bestowal of freedom, especially when a long time had passed since the individual in question had been released. Instead of passing from the status of slavery to the status of freedom, which occurred in the freedom lawsuits, the processes of re-enslavement addressed the possibility and the very legitimacy of the transition from freedom to slavery.

Of the 402 lawsuits that went to the Court of Appeals of Rio de Janeiro in the nineteenth century, 110 involved either maintenance of slavery or maintenance of freedom. ${ }^{9}$ Although the number is relatively small, they allow us to perceive how unstable the situation of these freedpersons must have been, even for those who had lived as free for many years.

Assuming that those who had access to the courts were just a tiny portion of the number of freed or free persons threatened by their former or alleged masters, we must consider re-enslavement as a practice that was effective even in the late nineteenth century. After 1870 alone, for example, twenty cases came to the Court of Appeals of Rio de Janeiro (see chart 3).

Although these data reveal a great deal, the individual cases raise specific questions about the law. In order for re-enslavement to be effective or to give rise to lawsuits, it had to have existed in the law. So it is important to identify the laws that made these lawsuits possible as well as the legal precedents that were used effectively by lawyers, whether arguing in favor of slaves or masters. The cases also lead to historical questions about the nineteenth-century Brazilian justice system: after all, the lawsuits were only effective if they were taken seriously by the judges, if their legal arguments were accepted, and if the plaintiffs had a chance of achieving their goals. Therefore, it is crucial to know the extent to which an individual claim to force a person living as free to return to slavery was considered legitimate by contemporaries, especially after 1850 , when the African slave trade was prohibited.

Some authors, including Lenine Nequete, have argued that legislation on enslavement and maintenance of freedom lawsuits was based on the law [decree] of March 10, 1682, which instituted repressive measures on the residents

9. It is important to emphasize that, in that paper, we are dealing with a very specific universe: a group of lawsuits that had their decision appealed and were sent to the Court of Appeals. At this stage, there were a lot of lawsuits whose sentences had been appealed by the losing party as much as there were those whose sentences had disadvantaged the slaves. In the latter cases, the appeal was made ex-officio, ie, automatically. In this regard, see Grinberg, Liberata. 
Chart \#3 Occurrences of Enslavement Lawsuits throughout the nineteenth Century

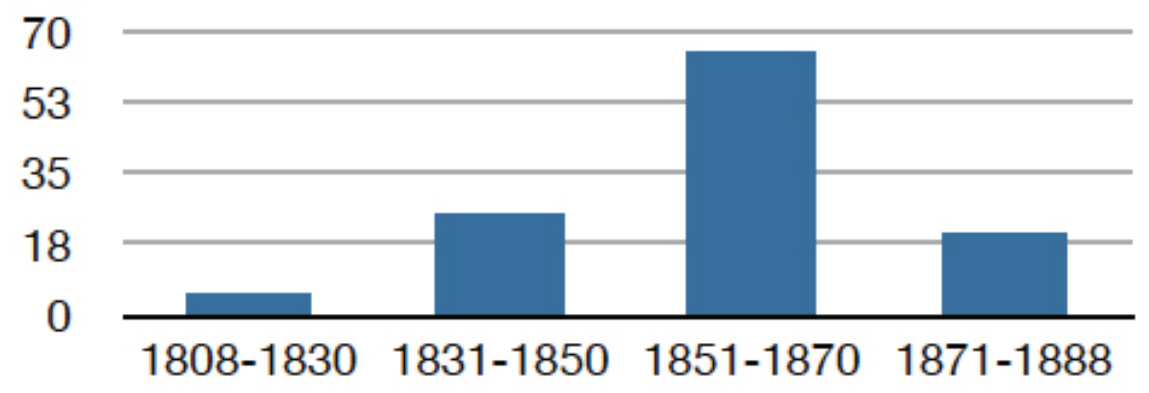

Source: Court of Appeals-National Archives-Rio de Janeiro.

of the maroon community (quilombo) of Palmares. ${ }^{10}$ The law stated that all those who had been slaves before they fled to the quilombo should be returned to slavery if their masters claimed them within five years:

[A person who] is de facto free but lawfully a slave may be claimed by his master solely within the period of five years, counting from the day he became obedient to me [that is, counting from the date the slave began living as free]; at the end of that period this claim will be considered outside the statute of prescription. ${ }^{11}$

It is curious that in all of the enslavement lawsuits surveyed, however, this law itself was cited only once, in the case of Martha and Sabino, and only five times in the maintenance of freedom cases. If we count all 402 freedom lawsuits from the Court of Appeals of Rio de Janeiro between 1808 and 1888, the law of March 10, 1682 was mentioned only sixteen times.

Four laws were cited most frequently in the enslavement and maintenance of freedom cases: Article 179 of the Brazilian Constitution; the law of June 6, 1755; and Title 64 and Title 11 paragraph 4 from Book 4 of the Ordenações Filipinas of 1604 (see table 1).

10. On the repression of the Maroon community of Palmares, see Silvia Lara, "Do singular ao plural: Palmares, capitães-do-mato e o governo dos escravos," in: João José Reis e Flávio dos Santos Gomes (orgs.), Liberdade por um fio, São Paulo, Companhia da Letras, 1996, p. 81-109.

11. Law of March, 10, 1862, paragraph 5, Apud Lenine Nequete, O escravo na jurisprudência brasileira: magistratura e ideologia no Segundo Reinado. Porto Alegre: Revista dos Tribunais, 1988, from p. 263 on. explanatory parenthesis by Lenine Nequete. 
TABLE 1: Legal Authorities Cited in Reenslavement Lawsuits

\begin{tabular}{llc}
\hline Law & \multicolumn{1}{c}{ Subject } & Number of quotes \\
\hline Constitution, art. 179 & $\begin{array}{l}\text { Civil and Political } \\
\text { rights: freedom, } \\
\text { security and property }\end{array}$ & 24 times \\
Ordenações Filipinas book 4 & $\begin{array}{l}\text { "in favor of freedom are } \\
\text { granted many things } \\
\text { against the general rules.” }\end{array}$ & 22 times \\
Litle 11 paragraph 4 & $\begin{array}{l}\text { Freedom of indigenous people } \\
\text { Ordenações Filipinas book 4 }\end{array}$ & Revocation of manumission \\
title 63 & 13 times & 13 times
\end{tabular}

Source: Court of Appeals-National Archives-Rio de Janeiro. Total of lawsuits analyzed in this table: 110

All four references were related in some way to the matters discussed in these lawsuits. ${ }^{12}$ The first two appeared in virtually all freedom lawsuits. Article 179 of the Brazilian Constitution, enacted in 1824, which deals with the inviolability of property, was quoted by advocates of slave owners, to defend the legality of the removal of their property without their consent. The Ordenação of Book 4, Title 11, paragraph 4 was mentioned by all trustees of slaves: "in favor of freedom are granted many things against the general rules." ${ }^{13}$

The last two laws already specifically included the issue of re-enslavement. The law of June 6,1755 , cited abundantly throughout the nineteenth century, has nothing to do with the enslavement of Africans and their descendants: it forbids the enslavement of indigenous people in the provinces of Maranhão and Grão-Pará, reinforcing the intention of the King of Portugal to instruct the Indians in the Catholic faith, a mission which "will never be achieved if not through their own effective means of civilizing themselves"-an impossible objective if they remained in captivity. ${ }^{14}$

No direct reference authorized the application of this law in freedom lawsuits related to Africans, but there was also no restriction on its application,

12. The phrase may seem strange, at first; all of the above mentioned legislation should make reference to the subject discussed in the process. Sometimes, however, the cited legislation concerned administrative procedural issues, such as deadlines, formats, citations, etc.., Not related directly to the main subject matter in question.

13. In fact, the text of the ordinance states that "no one shall be compelled to sell their inheritance and possesions against their will," but clarifies that the situation of the captives (Moors, made captive during the time of the Reconquista in Portugal) should be considered differently. To comment on this ordinance and the full text, see Keila Grinberg, O fiador dos brasileiros, p. $119-24$ and $367-8$.

14. About the enslavement of Indians, see Monteiro, Negros da Terra. See also, Ronaldo Vainfas, Ideologia e Escravidão: os letrados e a sociedade escravista no Brasil colonial, Petropolis, Vozes, 1986. See also César Tripoli, História do Direito Brasileiro, São Paulo, Revista dos Tribunais, 1936, p. 140-144. 
and there was no other law that substituted for it. This seems to explain why it was cited in 49 , or more than $10 \%$, of the 402 liberty suits. ${ }^{15}$

In contrast, Book 4, Title 63, of the Ordenações Filipinas- "Of the donations and manumissions that can be repealed because of ingratitude"-as the title itself proclaims, specifically addressed the revocation of manumission. In this case, as the nineteenth century jurist Perdigão Malheiro emphasized, following the origins of Roman law, freedom could be annulled in the case of "grave insult" to the benefactor by the freedperson; physical injuries inflicted on the master by the former slave; business deals contracted by the freedperson that brought damages to the former master; unfulfilled promises on the part of the freedperson, and even "any personal ingratitude, even if verbal, if it is expressed in the absence, not the presence of the patron."16

While Title 63 of Ordenações Filipinas was widely cited in the lawsuits, the law of March 10, 1682, which established the five-year prescription on reenslavement, was barely mentioned by the lawyers and judges in these cases. The use of the first benefited the owners, while the second would be favorable to the slaves.

If we look at the distribution of the data over time, however, we see a different situation (see chart 4). While the citations of Book 4 Title 63 of the Ordenações Filipinas are largely limited to the cases heard before the early 1860 s, the law of March 10, 1682 begins to appear in the proceedings after then.

Lenine Nequete has observed a similar phenomenon, noting that he did not find any reference to the law of March 10, 1682 prior to 1862 . The explanation for this dramatic change in legal arguments can be found in the 1862 Supreme Court judgment in case of Rosalina Fernandes de Almeida and her young children. The Court decided that because Rosalina had been living as free for more than six years, she should be considered free "by virtue of the prescription of five years, decreed in paragraph 5 of the Law of March 10, 1682."17 The judgment went on to cite the portion of the law that justifies the period of prescription:

... [it] not being in the interest of the political government of ... my State of Brazil, that, for longer than said time period, freedom remain uncertain

15. See comments on this law in Grinberg, O fiador dos brasileiros, pgs. 220-223.

16. Agostinho Marques Perdigão Malheiro, A escravidão no Brasil-ensaio histórico, jurídico, social, Petrópolis, Voices / INL, 1976 (1866), vol. 1, p. 167.

17. Nequete, $O$ escravo na jurisprudência brasileira, pg. 265. After judicial review, the case was submitted to the Court of Appeals of Pernambuco, where it came to a final judgment. Nequete only had analyzed the judgments of the Supreme Court, for this reason, he was unaware of the decisions and arguments cited in the proceedings in which the final judgment was made in the Court of Appeal as mentioned earlier in this text. 
Chart \#4: Patterns of Citation of the Ordenações Filipinas Book 4 title 63 and the Law of March 10, 1862 in the Enslavement Lawsuits

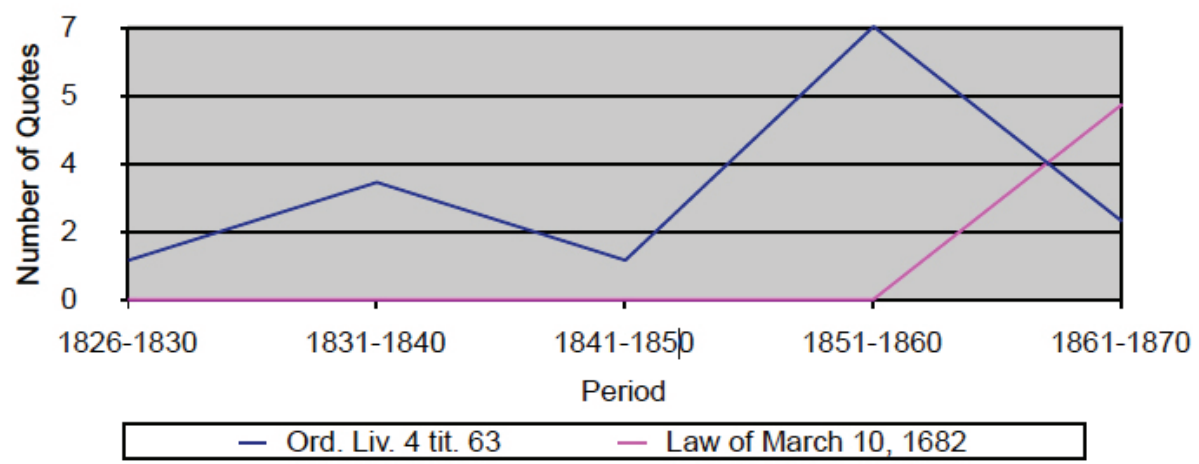

Source: Court of Appeals-National Archives-Rio de Janeiro. Total of lawsuits analized in this chart: 110

in those who possess it, carelessness or negligence lasting longer should not benefit masters.

If uncertainty about the civil status of the population was inconvenient for the government of Brazil in 1682, it was all the more so in 1862. For this reason, the Supreme Court, citing the Law of March 10, 1682, recognized that

Although this law was issued under special circumstances, the public interest explicated in the same paragraph is nonetheless generic, conforming to the overarching Christian and humanitarian spirit of the legislation that governs us, and repeated acts of the Supreme Government have provided for the wretched [miseráveis] (as they are referred to in the law) who are subjected to slavery. ${ }^{18}$

Here it is necessary to examine more carefully the "special circumstances" of the Law of March 10, 1682. Returning to the text of the law, we see that its original purpose was to reinforce the status of captives who were slaves before they arrived in Palmares, as well as those who were born there of slave mothers. It is in this context that we understand paragraph 3 of the law, which states:

If some who by this law should be free are publicly held to be captives [termos de fato notório], they shall be returned to freedom by judicial order;

18. "Acórdão de 6 de dezembro de 1862, proferido pelo Supremo Tribunal de Justiça”, Revista do Instituto da Ordem dos Advogados Brasileiros, anos I e II, 1862/1863. Edição fac-símile, número especial, ano XI, 1977, p. 22. 
and when the holding is not public [fato não seja notório], and they intend to sue the masters, they can do so during the entire period [of five years] before a competent judge, who shall oblige said masters to give them the necessary days to seek counsel and petition for justice, naming a lawyer to represent them, who will be paid by my treasury, when the judge determines that they lack the means ... and in either case, the case will be expedited due to the damages that otherwise would accrue to both the masters and the slaves due to the delay in common [ordinary] lawsuits. ${ }^{19}$

What the Supreme Court did was to interpret the 1682 law broadly, disregarding its original significance and removing it from the context of a specific event in time, in order to utilize the reasoning delineated in the letter of the law by updating it. Confusion about the freedom of individuals, in addition to allowing abuse by masters, could be taken again as harmful to the State, so the "question of public interest" was to be considered generically, i.e. relevant to any time either in the 17 th century or the nineteenth century. So, too, was the (political) decision to set the period of five years for prescription of slavery, and not 10 or 20 , as had been discussed up to then. ${ }^{20}$

The same usage of the Law of March 10, 1682-or rather, the same political interpretation of the law-was adopted by Perdigão Malheiro when he used its paragraphs 2 and 3, in addition to the law of June 7, 1755, to claim that the Portuguese-Brazilian Law had maintained the presumption that "every man is free by nature." The jurist also advocated the establishment of a period of five years for the statute of limitation regarding re-enslavement. For him, this period was based on Roman slave law, which was rigorous regarding fugitive slaves. If they were caught, no matter how long they had lived as freedpersons, they were returned to captivity. Gradually, however, the law became less rigorous: the emperors Diocletian and Maximian established the term of twenty years of continuous possession of freedom as sufficient for the statute of limitation regarding re-enslavement. Justinian established the period of ten years; later still it was reduced to five.

In addition to the length of the statute of limitations period, Perdigão Mal-

19. Apud Lara, Legislação sobre escravos africanos na América Portuguesa, p. 42. Mais uma vez, as referências sobre o alvará de 1682 incluem as observações sobre a leitura que dele faz Perdigão Malheiro e estão baseadas na análise feita por Silvia Lara.

20. The treatise by Mafra establishes the period of twenty years; for Correia Teles, the peaceful possession of liberty for ten years precluded a legal action of maintenance of slavery. Manuel da Silva Mafra, Jurisprudence of the Courts, compiled from published judgments of the Superior Courts since 1841, Rio de Janeiro / Paris, BLGarnier / Durand Lauriel and Pedone, 1868, vol.1, p. 192-193; José Homem Correia Teles, Digesto português, volume II, Coimbra, J. Bookstore Augusto Orcel, 1860, 5th edition, paragraph 1293. See also José Prospero Jeová da Silva Coroatá, Apanhamento de decisões sobre questões de liberdade publicadas em diversos periódicos forenses da Corte, Bahia, Typography Camillus de Lellis C. Masson, 1867, p. 101-19. Apud: Lenine Nequete, O escravo na jurisprudência brasileira, p. 271, note 8. 
heiro also cited other limitations on owners' petitions for redress against their alleged slaves, for example, when the slave was serving the State, especially in wars. But Perdigão Malheiro's main argument for fixing the period of five years was the law of 1682. In citing it, he knew he was changing its original intent; however, it served to explicitly support his argument in a disagreement with Correia Telles, who had defined the term as ten years. ${ }^{21}$

It is important to stress the importance of the maneuver by which both Perdigão Malheiro and the Supreme Court displaced the significance of the 1682 law when they applied it in the $1860 \mathrm{~s}^{22}$ They, along with the lawyers who drew on their interpretations, purposely ignored the context that gave rise to the law, giving it totally different meanings than that intended by the legislator at the time it was written. As Silvia Lara has stressed, what these lawyers and jurists were doing was much more than a "political reading of colonial law."

[they] invested in the body of Portuguese law concerning issues relating to slavery (including that of indigenous slavery) and read them in such a way as to create or construct a legal tradition that supported legal action in favor of "the burning and palpable issue of the extinction of slavery in our nation," as Perdigão Malheiro put it. ${ }^{23}$

The Supreme Court magistrates returned to this issue in 1879 , when they delivered another judgment based on the law of 1682, bestowing on the letter of the law an even broader interpretation than that of 1862 . The case was as follows: the master Bento Mariano da Costa Leite wanted the minors Teodoro, Rosendo and Marcolino to be returned to his custody. Costa Leite was the owner of the slave Sebastiana, whose daughter, Anastasia, had escaped eighteen years earlier, in 1861. Sebastiana's grandchildren were born before the enactment of the Law of the Free Womb in 1871; their mother, Anastasia, was registered as "escaped," as well as her children (of whom the master had news through some maroons). The judge approved Costa Leite's petition for reenslavement, as did the Court of Appeals of Maranhão. The Brazilian Supreme Court, however, overturned these decisions, finding them "manifestly invalid and notoriously unjust."

The Court reasoned that there had been no evidence provided to demonstrate that Anastasia's children had been born before the enactment of the Law of the Free Womb; given this doubt, the two should be declared free. The other

21. Malheiro, A escravidão no Brasil. This observation, as well as in-depth analysis of the uses made by Perdigão Malheiro the law of 1682, were made by Silvia Lara in the "Introduction" to her Legislação sobre escravos africanos na América Portuguesa, p. 44.

22. Silvia Lara mentions reading Candido Mendes de Almeida on the subject, in her comments on the "Ordinances Philippines." Lara, Legislação sobre escravos africanos na América Portuguesa, p. 44-45.

23. Idem, p. 45. 
reason, however, is more surprising: the action of re-enslavement should be dismissed because, under the law of March 10, 1682, Anastasia could not be reenslaved by virtue of the statue of limitations, since she had been in possession of her freedom for more than five years. It mattered little to the Court that she was an escaped slave, or that, throughout this period, the owner had taken all reasonable steps to capture her, including having registered her as a runaway. The judges also ignored the question of whether the slave had ever enjoyed a "peaceful freedom," a condition required by the original 1682 law. In fact, Anastasia had only left the maroon community where she had taken refuge when it was destroyed by the authorities. Regardless, the Court considered the enslavement lawsuits unfounded, because they were filed outside of the statute of limitations for re-enslavement. And the grandchildren of Sebastiana were freed..$^{24}$

The two decisions of the Supreme Court-regarding the case of Rosalina in 1862 and of Anastasia in 1879-as was to be expected, caused great controversy. An argument was also put forth, by the very famous lawyer Teixeira de Freitas, that the statute of limitations-which for him should continue to be for ten years-would only be valid if the slave had been living as free with the consent of his master, and had not been "removed from slavery," because "bad faith destroys this and all statutes of limitation."25

Despite the objections lodged by jurists, the effects of the jurisprudence established by the Supreme Court seem to have been substantial. As we know, the first judgment was widely publicized, having been published in the Revista do Instituto dos Advogados Brasileiros (Journal of the Institute of Brazilian Lawyers) in 1863 and in the compilation Jurisprudência dos Tribunais, organized by Manuel da Silva Mafra and published in $1868 .{ }^{26}$ In addition to that, 11 references to the law of 1682 were found in the lawsuits involving maintenance of freedom. Except for one from 1830, all were filed after $1862 .{ }^{27}$ Furthermore, the

24. Revista do Supremo Tribunal de Justiça, 9419 apud Lenine Nequete, O escravo na jurisprudência brasileira, pp. 266-268. The file was sent to the Court of Appeals of Pernambuco, which was decided in a less controversial manner: it considered the evidence that minors had been descended from the slave womb as "weak and unfounded" and could not, therefore, be sufficient to carry out the re-enslavement.

25. Augusto Teixeira de Freitas, Doutrina das ações acomodada ao foro do Brasil até o ano de 1877, Rio de Janeiro, BL Garnier, 1880, paragraph 23, note 44. Apud: Lenine Nequete, O escravo na jurisprudência brasileira, pp. 271-272, note 8. The political thought of the legal jurist has been extensively analyzed by Eduardo Pena Spiller, Pajens da casa imperial, chapter 1. Freitas reached the point of considering that the Law of the Free Womb, itself, was unconstitutional for violating the right of ownership of the masters, owners of the wombs of their slaves. (Nequete, O escravo na jurisprudência brasileira, pp. 283-284.)

26. Revista do Instituto dos Advogados Brasileiros ano II, tomo II, no. 1 (janeiro-março de 1863). Rio de Janeiro, Tipografia de Quirino Irmão, 1863, p. 20-3; Manuel da Silva Mafra, $A$ jurisprudência dos tribunais, $3^{\circ}$ vol. Apud: Lenine Nequete, op. cit., p. 266.

27. Other cases in which the Law of March 10, 1682 was cited occurred in 1862, 1863, 1864, $1866,1867,1868,1869,1871,1872,1873$ and 1880. 
numerous lawsuit transcripts published in the journal $O$ Direito in the 1870s and 1880s showed that the use of the Law of March 10, 1682 was much higher than would be expected from earlier practice. by ${ }^{28}$

The hypothesis I wish to defend here is that it was not by chance that, precisely in the 1860s, Supreme Court justices abruptly remembered to use a law already two hundred years old. Likewise, it was not random that title 63 of book 4 of the Ordenações Filipinas, began to fall into disuse at this same time.

It was again Perdigão Malheiro who explicitly stated that in the 1860s the revocation of manumission for reasons of ingratitude should be unacceptable. While recognizing that this legislation had not been expressly repealed and that there was still much to debate about it, he argued that "manumission is nothing more than the restitution of freedom owed to the slave, which, therefore, can no longer be taken for any reason." ${ }^{29}$

The existence of slavery itself was probably not such a serious problem for jurists such as Ribas, Trigo de Loureiro, Teixeira de Freitas or even Perdigão Malheiro. For the last two, it certainly was not. But although the institution of slavery was still acceptable, it was increasingly difficult to justify the possibility of re-enslavement, mainly because, in Brazil, freedom also implied the acquisition of citizenship rights. ${ }^{30}$ Thus, a revoked manumission implied not only return to slavery, but also the loss of all rights by a person in possession of them as a citizen.

It seems that the diagnosis of Malheiro about the "reason and conscience" of each judge "in the times in which we live" made sense. In effect, by the 1860s, judges had come to accept certain arguments as valid, even seeking legal precedents that did not correspond directly with the case in question, such as the law of 1682 . At the same time, other arguments were gradually losing legitimacy and the legal precedents that they had been based on were being abandoned, such as the Title 63 of Book 4 of the Ordenações Filipinas, about the revocation of manumission. Perhaps for this reason, the number of cases that had reenslavement as a central theme grew (see chart 5). While there were still many cases decided in favor of the slave owners-and there would continue to be until the 1880 s - this data shows that, at least since the 1830 s, more than $50 \%$ of the sentences of appealed cases were favorable towards freedom.

28. O Direito, vol. 17, 1878, pp. 261-265; vol. 22, 1880, pp. 617-637; vol. 26, 1881, pp. 196200; vol. 27, 1882, pp. 193-198; vol. 28, 1882, pp. 70-75; vol. 30, 1883, p. 399; vol. 36, 1885, pp. $107-114$.

29. Perdigão Malheiro, A escravidão no Brasil, vol. 1, p. 174.

30. For the concepts of Teixeira de Freitas and Perdigão Malheiro on slavery, see Spiller Eduardo Pena, Pajens da casa imperial, chapters 1 and 3. For a more general discussion of slavery and citizenship in Brazil, see Hebe Mattos, Escravidão e cidadania no Brasil Monárquico, Rio de Janeiro, Jorge Zahar, 1999 and Keila Grinberg, Código civil e cidadania, Rio de Janeiro, Jorge Zahar, 2001. 
Chart \#5: Results of Reenslavement Lawsuits in the nineteenth Century

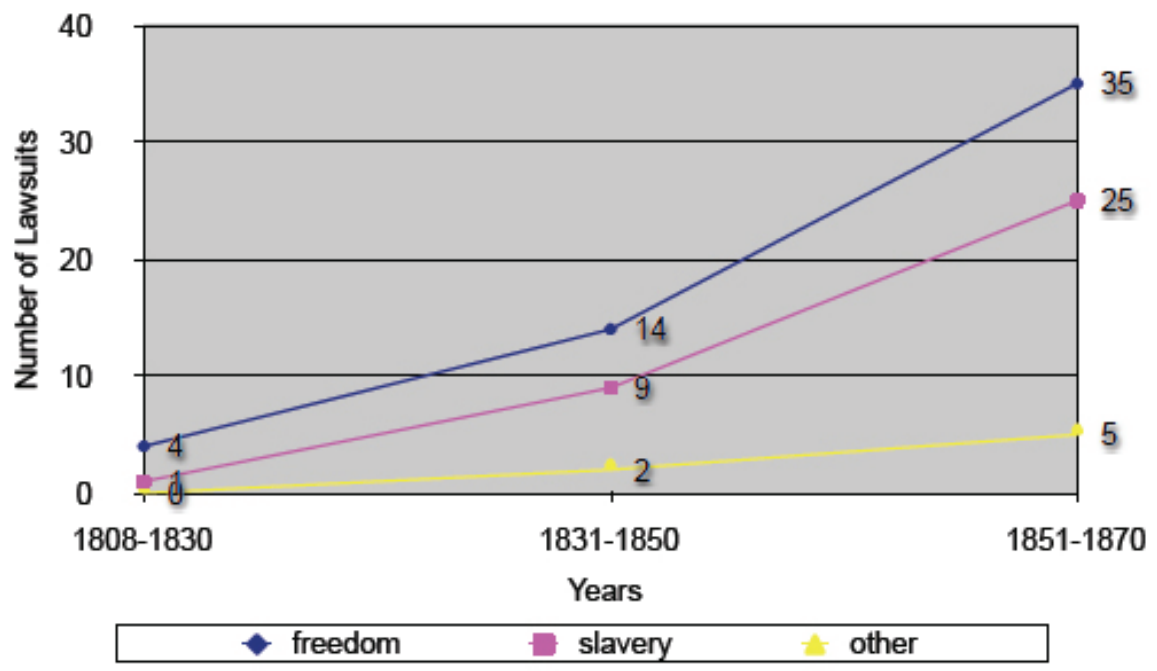

Source: Court of Appeals-National Archives-Rio de Janeiro. Total of lawsuits analyzed in this chart: 110

Chart \#6: Occurrences of Lawsuits involving Re-enslavement and the Maintenance of Freedom in the nineteenth Century

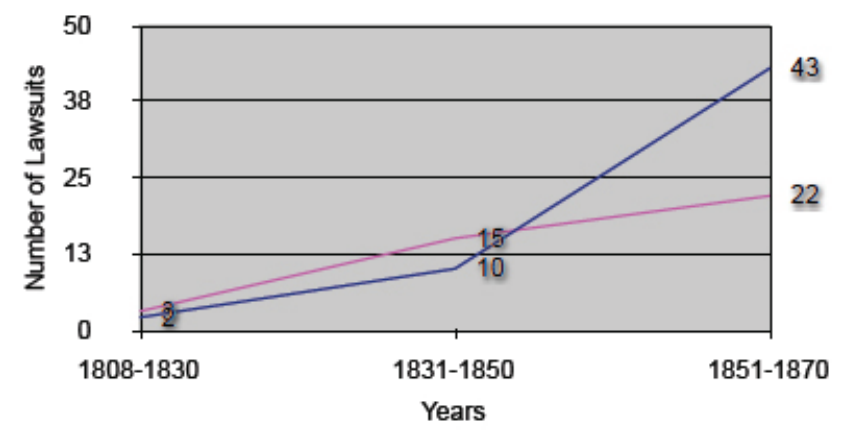

- Maintenance of Freedom $\quad-$ Enslavement Lawsuits

Source: Court of Appeals-National Archives-Rio de Janeiro. Total of lawsuits analized in this chart: 110 
Also, as shown in the chart 6, the number of maintenance of freedom lawsuits grew very sharply from 1850, while the re-enslavement lawsuits followed a trend quite different: although their number had not fallen, their growth was much smaller.

The analysis of these two charts allows us to reach two important conclusions. The first is that, after 1850, more slaves filed maintenance of freedom lawsuits in the courts than masters initiated re-enslavement lawsuits. Although these data indicate the occurrence of effective practices of re-enslavement, they cannot measure the full extent of the practice, which may have been in decline. It may salso be that slaves were aware of their chances of getting manumission in the courts, and willing to invest scarce resources in the effort. This is the second and more important conclusion: although it is difficult to make a strong argument based only on these data, it is possible that the slaves knew that their chances of victory in the re-enslavement lawsuits and maintenance of freedom cases were greater than those of their masters, at least in the Court of Appeals. ${ }^{31}$

That is why these data tells us a lot about the legal legitimacy of slavery in the second half of the nineteenth century: it demonstrates that, alongside what was happening in the streets, in the courts-at least in the appellate courtsthe legitimacy of slavery and its correlate of enslavement had suffered a serious blow.

Here we can return to the case of the persons formally known to have been slaves, Martha and Sabino, who were considered captives after years lived as free, by the judge of Curvelo in 1860 . With the appeal of the sentence, the case ended up in the Court of Appeals of Rio de Janeiro. There, the discussion between Antonio Pereira Rebouças, the curator of the slaves, and, Miguel Borges de Castro Azevedo e Mello, the lawyer for the masters, brought novelties that gave an almost cinematic aspect to the case. The petition of the appellants states that most of the beneficiaries of the slavery lawsuit, the heirs of João Vaz da Silva, had given up the attempt to re-enslave the alleged captives. The reason? They no longer wanted to prosecute Martha and Sabino, who were, respectively, their nephew and cousin. They said that the freed Martha was the daughter of Pedro Vaz da Silva, and therefore, the sister of João Vaz da Silva, responsible for her release. Sabino, being the son of Martha, was also the nephew of his master.

It was exactly what the lawyer Antonio Pereira Rebouças had claimed, pointing out that the sentence would determine the re-enslavement of Martha and Sabino and, as such, was unjust. He also said that besides the injustice that

31. Because judgments favorable to the masters were automatically sent to the Court of Appeals, these results may also indicate a progressive difficulty in obtaining favorable rulings in the lower courts. This statement still lacks specific research on the courts of first instance; incidentally, there is yet to be made an important comparison between the performance of the courts of first and second instance decisions concerning freedom of slaves. 
it had promoted, the sentence was illegal because it considered the authors as the only heirs of the litigant João Vaz da Silva and because it neglected the power that the laws conferred upon husbands to dispose of all furniture and livestock acquired during the couple's "marital administration." 32

Azevedo and Mello made use here of the strategy to consider manumission as a donation like any other, exactly the opposite of the definition advocated by Perdigão Malheiro and others. To Azevedo and Mello manumission was a form of contract, which dealt with the transfer of ownership. Thus, the only difference between the donation of freedom and the other existing grants was that the grantee could not refuse it. But, possibly only in order to refute the argument that the court's decision was "unfair," he added that "it is not in a Court of Law that we deal with giving to each his own, that we are called upon to move emotion and cry for the rights of man to the guarantees of freedoms, sacrificed by greed and inhumanity. We have faith, and in its presence, beautiful theories and eloquent discussions are worthless." ${ }^{33}$

The lawyer for the alleged owners must have been trying to avoid a judgment based on the exceptional nature of regulations involving slavery and freedom, especially when these involved family relationships between masters and slaves. Butthey were thwarted.. The Court of Appeals of Rio de Janeiro not only recognized that, from a legal standpoint, the freed appellants were right, but also emphasized that the judge of Curvelo, in deciding to re-enslave Martha and Sabino, had committed what was then called "notorious injustice": he had complied with the claim of the plaintiffs / heirs of João Vaz to enslave their own relatives. The judges of the Court of Appeals thus in fact "vociferate[d] for the rights of man, for guarantees of freedoms"-exactly what Azevedo and Mello had tried to prevent in their arguments.

The judgment was endorsed by the Brazilian Supreme Court, which denied the alleged masters' request for review. At the end the heirs of João Vaz da Silva had been defeated in court by two freedpersons.

The argument that the judicial system represents the supposed interests of the elite still lingers in analyses of nineteenth century Brazil. "Law School graduates (bacharéis) of the whip" is just one-the strongest, perhaps-of the expressions used to describe the ways in which lawyers and judges defended the slave property of members of their supposed social class. ${ }^{34}$

Indeed, it is still presumed that even if it was possible for a slave to end up

32. Ação de liberdade, 1860. National Archives of Rio de Janeiro, Court of Appeals, box 3691, number 6229. I analyzed this same process in Keila Grinberg, O fiador dos brasileiros, pgs. 216-217.

33. Idem.

34. The author of that expression is Jurandir Malerba. Os brancos da lei-liberalismo, escravidão e mentalidade patriarcal no Império do Brasil, Maringá, Editora da Universidade Estadual de Maringá, 1994. 
winning a lawsuit against his or her master, the court's "logic" dictated that the legal reasoning was on the side of slave owners. The judiciary could not possibly serve to defend the rights of slaves. ${ }^{35}$

Analysis of the attitude of the slaves who appealed to the courts to fight for prerogatives that came to be understood as rights has contributed to questioning this view. After all, in freedom lawsuits, the responsibility for finding a reasonable resolution to the conflict was delegated to the justice system, even though in practice, this resource was sometimes merely a strategy to press masters to release their slaves sooner. The attitude of these slaves reveals that, at least from their perspective, the state had the power to enforce the rights they believed they had, including the right to receive freedom, which, at times, had only been verbally promised by a master.

It is clear that the Brazilian courts played an extremely important role in securing the emancipation of African slaves and their descendants. This importance is evidenced not only by the large number of freedom lawsuits, but also, primarily, by many rulings favorable to the effective liberation of slaves.

Freedom lawsuits in general thus played a key role in the conflict between the preservation of slavery and the process of modernization of the Brazilian state in the nineteenth century: they were an expression of the struggle for rights fought for by slaves and their descendants, who, through the justice system, made their demands public, and articulated the need for legal regulation of personal civil rights. In a way, their requests for state actions contributed to the expansion of the public sphere.

Moreover, recent work such as that by Elciene Azevedo and Beatriz Galotti Mamigonian has shown how, from the late 1860s onward, abolitionist lawyers and judges stormed the courts and established jurisprudence on issues of slavery and freedom. They did so by recognizing the possibility of new interpretations of old laws, such as that of November 7, 1831, the first to ban the Atlantic slave trade to Brazil. ${ }^{36}$

The existence of re-enslavement lawsuits, their outcomes, and the patterns in which citation of particular laws occurred, demonstrate that beginning in the 1860s, judges and lawyers (who in this case were as individuals far from abolitionist) were gradually recognizing that familiar re-enslavement practices,

35. This is, for example, the position of José Murilo de Carvalho, who argues that the Brazilian population in the nineteenth century, not sharing in the alleged bureaucratic concerns and modernizing of the independent state, had a negative relationship with it. José Murilo de Carvalho, "Cidadania: tipos e percursos," Estudos Históricos, vol. 9, no. 18, 1996, pp. 337-59; e Cidadania no Brasil, Rio de Janeiro, Civilização Brasileira, 2001.

36. Elciene Azevedo, $O$ direito dos escravos-lutas jurídicas e abolicionismo na província de São Paulo na segunda metade do século XIX. Campinas, Editora da Unicamp, 2010. Beatriz Mamigonian, To be a Liberated African in Brazil: labor and citizenship in the nineteenth century, $\mathrm{PhD}$ dissertation. Waterloo, University of Waterloo, 2002. 
were becoming less legitimate. As a result, he masters who took their disputes with their slaves to court had no a priori guarantee of victory.

Between the beginning of the loss of legitimacy and the actual loss of legality, which only occurred with the abolition of slavery, many years would pass. But perhaps it is not too much to say that from the mid-1860s, slaves and freedpersons had at least one stage-the Appeals Court-on which their claims were heard more favorably than their masters'. 